\title{
Epigenomic profiles of African American Transthyretin Vall 22lle carriers reveals putatively dysregulated amyloid mechanisms
}

Gita A Pathak, PhD ${ }^{1,2}$, Frank R Wendt, PhD ${ }^{1,2}$, Antonella De Lillo, PhD ${ }^{3}$, Yaira Z. Nunez, BS $^{1,2}$, Aranyak Goswami, PhD ${ }^{1,2}$, Flavio De Angelis, $\mathrm{PhD}^{1,2,3}$, Maria Fuciarelli, $\mathrm{PhD}^{3}$, Henry R Kranzler, MD $^{4}$, Joel Gelernter, MD ${ }^{1,2}$, Renato Polimanti, PhD ${ }^{1,2}$

\footnotetext{
${ }^{1}$ Department of Psychiatry, Yale School of Medicine, Yale University, New Haven, CT, USA

${ }^{2}$ Veteran Affairs Connecticut Healthcare System, West Haven, CT, USA

${ }^{3}$ Department of Biology, University of Rome Tor Vergata, Rome, Italy

4 University of Pennsylvania Perelman School of Medicine, VISN 4 MIRECC, Crescenz VAMC, Philadelphia, PA, 19104, USA
}

Corresponding author: Renato Polimanti, PhD

E-mail: renato.polimanti@yale.edu

Address: VA CT 116A2, 950 Campbell Avenue

West Haven, CT, 06516, USA

Phone: +1 (203) 937-5711 x5745

Fax: +1 (203) 937-3897 


\section{Abstract}

The Val122Ile mutation in Transthyretin (TTR) gene causes a rare, difficult to diagnose hereditary form of cardiac amyloidosis. This mutation is most common in the United States and mainly present in people of African descent. The carriers have an increased risk of congestive heart failure and several other non-cardiac phenotypes such as carpal tunnel syndrome, peripheral edema, and arthroplasty which are top reasons for ambulatory/outpatient surgeries in the country. We conducted first-ever epigenome-wide association study in Val122Ile carriers of African descent for heart disease (HD) and multiple outpatient surgeries (OS) - an early disease indicator. Five differentially methylated sites $(\mathrm{p} \leq 2.1 \mathrm{e}-08)$ in genes - FAM129B, SKI, WDR27, GLS, and an intergenic site near RP11-550A5.2 and one differentially methylated region containing KCNA6 and GALNT3 ( $\mathrm{p}=1.1 \mathrm{e}-12)$ were associated with HD. For OS, we observe four sites - two sites in UBE2E3 and SEC14L5, and other two in intergenic regions ( $\mathrm{p} \leq 1.8 \mathrm{e}-07)$ and three regions

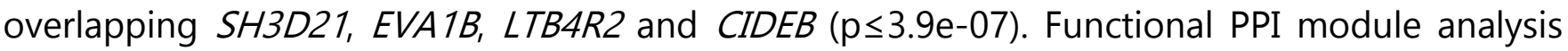
identified $A B C A 1(\mathrm{p}=0.001)$ for HS. Six cis-mQTLs were associated with one of the significant CpG sites (FAM129B; $\mathrm{p}=4.1 \mathrm{e}-24)$. We replicated two CpG sites (cg18546846 and $\mathrm{cg} 06641417 ; \mathrm{p}<0.05)$ in an external cohort of biopsy- confirmed cases of TTR amyloidosis. The genes identified are involved in transport and clearance of amyloid deposits (GLS, $A B C A 1, F A M 129 B$ ); cardiac fibrosis (SKI); and muscle tissue regulation (SKI, FAM129B). These findings highlight the link between a complex amyloid circuit and diverse symptoms of Val122Ile.

Keywords: amyloid, transthyretin, methylation, epigenetic, cardiac amyloidosis 
medRxiv preprint doi: https://doi.org/10.1101/2020.04.15.20066621; this version posted April 18, 2020. The copyright holder for this preprint

\section{Introduction}

Hereditary transthyretin amyloidosis, caused by specific disease-causing mutations, is due to

a gradual extracellular deposition of amyloid in multiple tissues primarily leading to several clinical signs and symptoms ${ }^{1}$. There are 113 known mutations in the transthyretin (TTR) gene ${ }^{2}$ giving rise to hereditary form of TTR amyloidosis. The tetrameric structure of TTR protein dissociates into dimers and monomers resulting in formation of fibrils. The aggregation of fibrils leads to deposition of "amyloid-fibrils" in multiple tissues causing onset of heterogenous symptoms ${ }^{2,3}$. Val122Ile is the most prevalent TTR gene mutation in the United States and observed in populations of African descent ${ }^{4}$. The Val122Ile is a point mutation (variant rs76992529) resulting in substitution of isoleucine with valine at 122 position. Extensive amyloid deposition seems to resemble hypertrophic cardiomyopathy such as enlargement or wall thickening leading to heart failure and atrial fibrillation ${ }^{5}$. These symptoms often are attributed to other population-prevalent cardiovascular risk factors resulting in underestimation of the clinical penetrance of the Val122Ile ${ }^{6}$. The estimated age of onset for non-cardiac precursor phenotypes for hereditary transthyretin amyloidosis is between 30 to 40 years of age ${ }^{7}$. In two retrospective studies, carpal tunnel syndrome preceded hereditary transthyretin amyloidosis diagnosis by 910 years $^{8,9}$. According to The Transthyretin Amyloid Outcome Survey (THAOS), several cardiac, gait, gastrointestinal, neurological and renal disorders are prevalent in Val122Ile carriers ${ }^{4}$. Parallel to these findings, another study reported phenotypes associated with TTR mutations such as atrial fibrillation, myopathy related to ventricular thickness, gastrointestinal and kidney dysfunction including nausea, vomiting, and neuromuscular dysfunction ${ }^{10}$.

Recently, we reported a combined association of heart disease history and having had 10 or more outpatient (ambulatory) surgeries with Val122Ile mutation in individuals of African descent $^{11}$. One of the top reasons for ambulatory surgery in the United States is arthroplasty ${ }^{12}$, which occurs in TTR-carriers years before the expected cardiac dystrophy at advanced ages ${ }^{13}$. These epidemiological findings indicate that atypical phenotypes occurring earlier in life could be connected to the risk of heart failure in Val122Ile carriers. Findings from several studies including ours raise the possibility of non-regulatory molecular factors contributing to the 
medRxiv preprint doi: https://doi.org/10.1101/2020.04.15.20066621; this version posted April 18, 2020. The copyright holder for this preprint

genotype-phenotype correlation ${ }^{10,14-17}$. Therefore, understanding the underlying biological changes in Val122Ile carriers is key to explaining the symptom heterogeneity and earlier onset of atypical phenotypes.

DNA methylation is a heritable non-coding regulatory mechanism causing phenotypic variation $^{16}$. Epigenetic modifications arising from the addition of methyl groups on cytosinephosphate-guanosine $(\mathrm{CpG}) \operatorname{sites}^{18}$ could contribute to molecular mechanisms involved in TTR amyloidosis. So far, no study has investigated this hypothesis. Aberrant methylation profiles have been implicated in increasing accelerating the progression of common and rare diseases ${ }^{19}$. The accumulation of amyloid-fibrils within or around cellular structures of the tissue result in damage invoking an immune response ${ }^{20}$. The inter-individual variation in response to site of damage invokes an acute phase response ${ }^{20}$. DNA methylation profiles have the potential to capture individual-level variability and highlight mechanisms involved in TTR amyloidosis ${ }^{21}$. Thus, we conducted the first epigenome-wide association study of TTR Val122Ile carriers to investigate the association of methylation changes with medical history of heart disease and outpatient surgeries.

\section{Methods}

\section{I Cohort description}

Carriers of Val122Ile (rs76992529*G >A) risk allele were selected from the Yale-Penn cohort, ${ }^{22-}$ ${ }^{25}$ whose medical history was obtained as part of the phenotyping effort, as previously reported ${ }^{11}$. The Yale-Penn study was approved by the institutional review boards at each participating site. The current study was approved under the protocol 2000023750 by the institutional review board (IRB) at Yale University School of Medicine.

We investigated two binary phenotypes - self-reported history of heart disease (" Has a doctor ever told you that you have (had) a heart disease?') and having had 10 or more outpatient surgeries. We previously reported that these two phenotypes were associated with the Val122Ile mutation in the Yale-Penn cohort ${ }^{11}$. We assayed 104 African Americans, samples from 8 of which failed the assay, leaving 96 carriers for analysis (mean age $=42.16 \pm 9.9$ [SD] yrs.). Epigenomic 
medRxiv preprint doi: https://doi.org/10.1101/2020.04.15.20066621; this version posted April 18, 2020. The copyright holder for this preprint (which was not certified by peer review) is the author/funder, who has granted medRxiv a license to display the preprint in perpetuity.

differences were tested with respect to the history of heart disease ( $N=90$ controls; 6 cases; Males-47\%) and 10 or more outpatient surgeries ( $N=94$ controls, 2 cases; Males-46\%).

The significant methylation sites were investigated in an independent cohort of Italian participants of European descent. This study included 48 carriers of TTR mutations (Val30Met, Phe64Leu, Ile68Leu, Ala120Ser, and Val122Ile) with the diagnosis of TTR amyloidosis confirmed via positive amyloid fibril deposition in their cardiac tissue biopsy samples, in addition to clinical symptoms. Thirty-two healthy individuals with none of the TTR mutations or clinical symptoms from the same local area were recruited as controls. Detailed information regarding this cohort was previously reported ${ }^{14,26}$. The methylation array analysis was performed at the Connecting Bio-research and Industry Center, Trieste, Italy, using the same sample protocol implemented in the Yale-Penn cohort.

\subsection{Sample and array processing}

DNA was extracted from whole blood of Yale-Penn participants using the EZ-96 DNA methylation kit (Zymo Research, CA, USA). As previously described ${ }^{25}$, the samples were genotyped at the Yale Center for Genome Analysis (YCGA), the Center for Inherited Disease Research, and the Gelernter laboratory at Yale (VA CT) using genome-wide arrays (Illumina HumanOmni1-Quad v1.0 and Illumina HumanCoreExome arrays), the imputation was performed with IMPUTE2.0, and principal components were derived on the QC'd genomic data. The Val122Ile - rs76992529 probe was genotyped in the HumanCoreExome array and imputed in the HumanOmni1-Quad v1.0 array with high imputation quality (INFO score $=0.98$ ) to determine TTR carriers in the African-American Yale-Penn participants ${ }^{11}$. DNA methylation was assayed using the Illumina Infinium MethylationEPIC chip quantifying $>850,000$ CpG sites and imaged on the Illumina iScan system at YCGA. The methylation intensity data ( ${ }^{*}$.idat files) was exported for analysis using the manufacturer's recommended protocol using the GenomeStudio methylation module.

\subsection{DNA methylation analysis}


medRxiv preprint doi: https://doi.org/10.1101/2020.04.15.20066621; this version posted April 18, 2020. The copyright holder for this preprint

(which was not certified by peer review) is the author/funder, who has granted medRxiv a license to display the preprint in perpetuity.

All analyses were performed in R 3.6. The methylation intensity files ( ${ }^{*}$.idat) were imported into ChAMP 27 for post-processing and normalization. The beta values, ranging from 0 to 1 were generated for all CPG sites representing the ratio of methylated to unmethylated fluorescent intensities. Primary QC removed CpG sites with low detection p-value, missing beads, sites near SNPs, multi-hit and non-autosomal sites. The beta values of the remaining 737,385 sites were normalized using the beta mixture quantile (BMIQ) method, followed by analysis of batch effects using singular vector decomposition. Technical batch effects for array and slide were corrected using ComBat. The blood cell-type composition and smoking status ${ }^{28}$ was derived from methylation data. The association analysis for CpG sites was performed on M-values (transformed beta values) using empirical Bayes methods implemented in the limma package. The association was adjusted for age, sex, tobacco use, smoking, genotype-derived principal components 1-10, and blood cell type proportions: CD8+T cells, CD4 + T cells, natural killer cells, B-cells, monocytes, and neutrophils. Genomic inflation was calculated using the QQperm package; both phenotypic associations had a lambda of 1 or less (Heart Disease - 1.01 and Outpatient Surgery - 0.92) indicating lack of population substructure bias. Due to the unbalanced case-control proportions, we also performed permutation of the association using the CpGassoc package $^{29}$. Differential methylation of regions was calculated using DMRcate. The sites and regions were deemed significant considering a false discovery rate of $<0.05$ (FDR $\left.R_{p-v a l u e}<0.05\right)$. Differentially expressed PPI network modules were investigated using the FEM package ${ }^{30}$. Gene ontology using significant genes mapped from significant CpG sites and regions was assessed with Shiny $G O^{31}$. The cis-methylation QTL (association between SNPs and significant methylated CpG sites) was performed with all the aforementioned covariates using Matrix $Q T L^{32}$, wherein the local distance was defined using the biologically expected and default value of $1 \mathrm{Mb}$ between SNP and CPG sites. Significant associations were identified using genomic control adjustment (GC) $p$-values $<0.05$, in addition to $F D R_{p-v a l u e}<0.05$. Epigenetic age - defined as the cumulative score of specific CpG sites across the genome -- was calculated using Hannum and Horvath's clock from the wateRmelon package $\mathrm{e}^{33}$. As suggested by the developers of each of the epigenetic clocks, biological age, and chronological age were significantly correlated, $R \geq 0.90 ; p<0.001$. The 
medRxiv preprint doi: https://doi.org/10.1101/2020.04.15.20066621; this version posted April 18, 2020. The copyright holder for this preprint (which was not certified by peer review) is the author/funder, who has granted medRxiv a license to display the preprint in perpetuity.

difference in the epigenetic (biological) age between cases and controls was tested using Student's t-test. The network connecting all of the significant genes detected from the above analyses was constructed using GeneMANIA ${ }^{34}$. The results were visualized using ggplot2, $\mathrm{COMET}^{35}$, and $\mathrm{FUMA}^{36}$.

\section{Results}

\section{I Differentially methylated sites}

We investigated differentially methylated sites with respect to two binary outcomes: - a) selfreported heart disease and b) a history of 10 or more outpatient surgeries. After performing the recommended quality control procedure, we investigated 737,385 sites in 96 individuals. In addition to performing standard association analysis, we permuted the phenotypes ( $p_{p e r m: ~} p$ value from permutation), which accounted for the case-control imbalance, yielding nine significant CpG sites (Figure 1). Five sites were hypomethylated in individuals with heart disease: cg06641417 (FAM129B; $\left.\log F C=-1.822 ; \quad p_{p e r m}=1.6 e-08\right), \quad \operatorname{cg} 26033908 \quad$ (SKI $\log F C=-1.615$; pperm=1.7e-08), cg14890866 (WDR27; $\log F C=-2.028 ;$ p perm=3.0e-08), cg15522719 (GLS; $\log F C=-$ 1.731; $p_{\text {perm }}=4.7 e-08$ ) and $\mathrm{cg} 18546846$ (intergenic; $\log F C=-0.786 ; p_{\text {perm }}=2.2 e-08$ ). The CpG sites mapped to FAM129B and SKIare located in gene bodies, cg14890866 is between the 5'UTR (UnTranslated Region) and TSS200 (- 200 nt upstream of Transcription start site ${ }^{37}$ ) of WDR27, while cg15522719 is in TSS150 at GLS. Four methylation sites were associated with 10 or more outpatient surgeries: cg13998023 (UBE2E3; logFC=-2.632; pperm=1.8e-07), $\quad$ cg05189127 (intergenic; $\log F C=1.885 ;$ perm=1.4e-07), cg03718655 (SEC14L5; logFC=-2.673; $\left.p_{\text {perm }}=1.5 e-07\right)$ and cg25814327 (intergenic; logFC=-2.075; $\mathrm{p}_{\text {perm }}=3 \mathrm{e}-08$ ). Three sites were hypomethylated, while cg05189127 (intergenic) was hypermethylated. The two sites that were annotated to genes were in the 5'UTR (UBE2E3) and TSS200 (SEC14L5). Details of the association result and annotation are reported in Supplementary file1 (Table S1). 


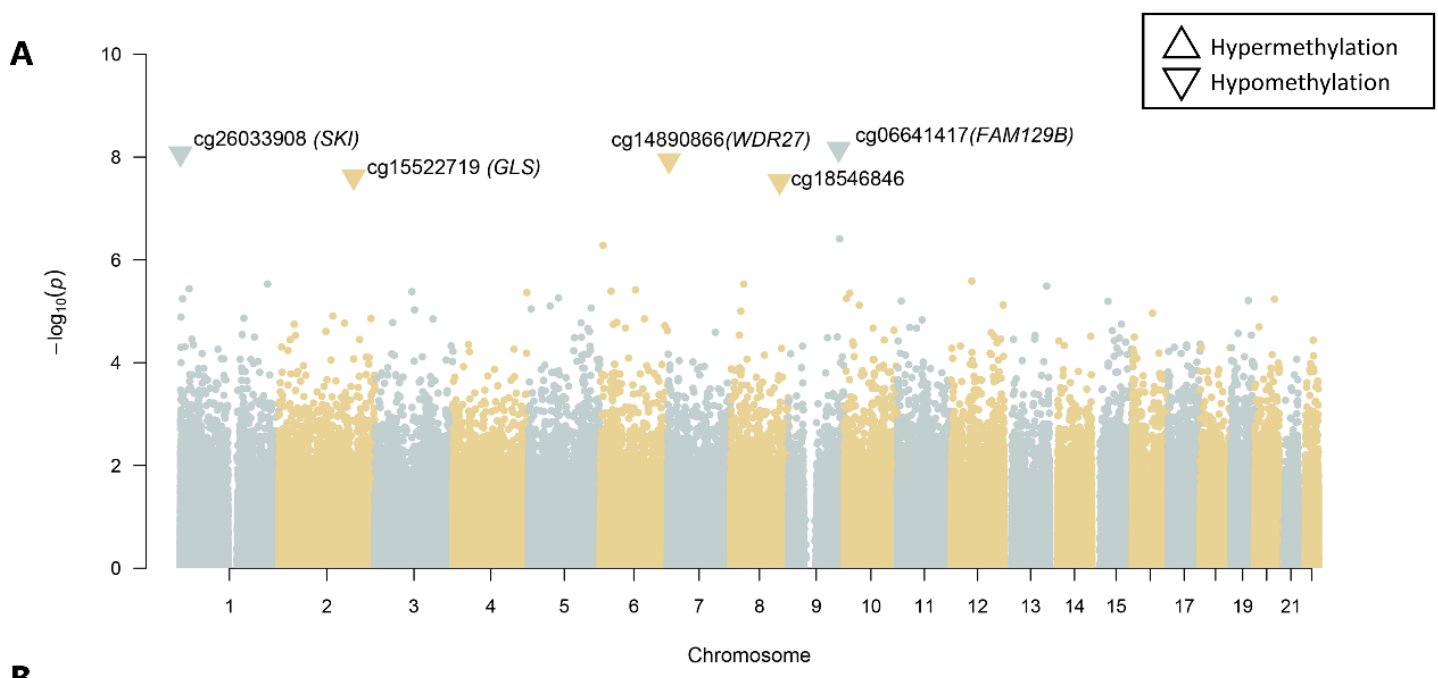

B

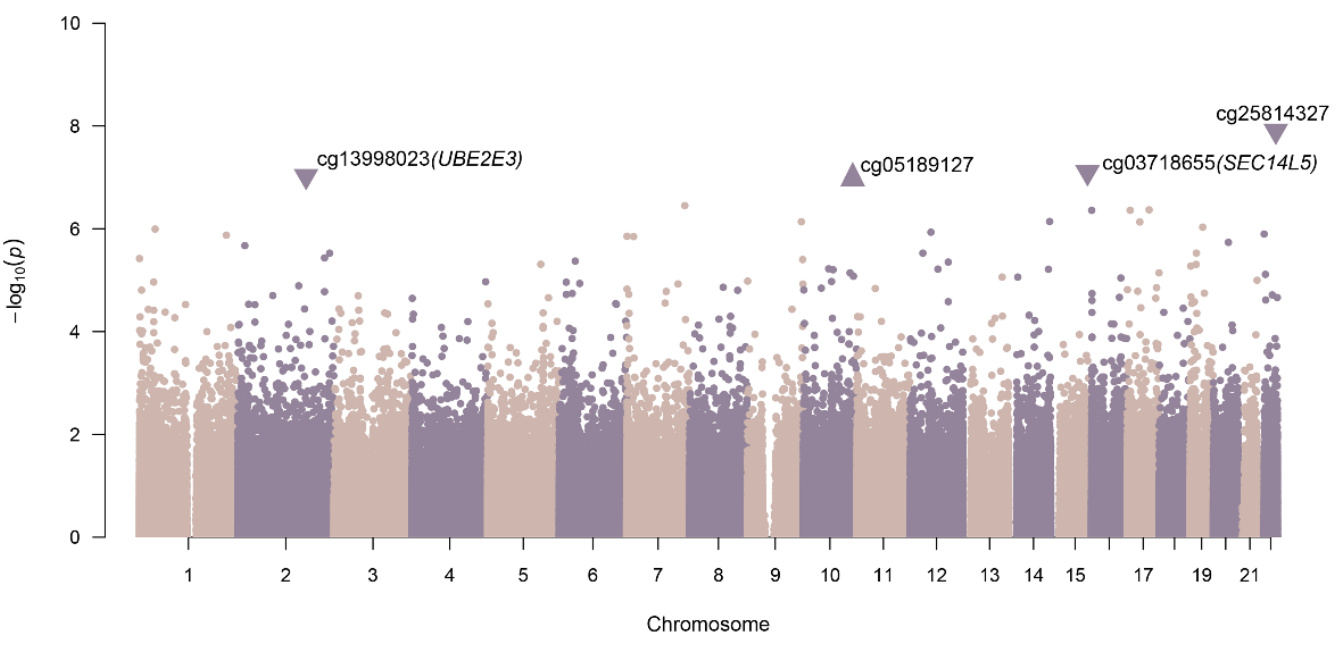

Figure 1: Differentially methylated sites in African American TTR-Val122Ile carriers. (A) Methylation sites that were significantly associated with medical history of heart disease. (B) Methylation sites that were significantly associated for having had 10 or more outpatient surgeries. Each CpG site is represented as a data point, with the $x$-axis being the genomic location and the $y$-axis is the -log 10 of the $p$-value of the CpG site. Significant sites are shown as triangles and labelled with genic annotation in parentheses, triangles pointing upwards signify hypermethylation, whereas triangles pointing downwards signify hypomethylation.

\subsection{Differentially methylated regions}

For heart disease, one region on chromosome 12 overlapping KCNA6 and GALNT3 $(\mathrm{p}=1.1 \mathrm{e}-$ 12) was differentially methylated. Associations with more than 10 outpatient surgeries were identified on chromosome 1 (SH3D21; EVA1B; $\mathrm{p}=1.3 \mathrm{e}-09$ ), chromosome 10 (intergenic region; $\mathrm{p}=1.7 \mathrm{e}-08)$ and chromosome 14 (LTB4R2; CIDEB; $\mathrm{p}=3.9 \mathrm{e}-07)$. Methylation levels among all sites were positively correlated within each region. (Figure 2; Supplementary file 1; Table S2) 
medRxiv preprint doi: https://doi.org/10.1101/2020.04.15.20066621; this version posted April 18, 2020. The copyright holder for this preprint

(which was not certified by peer review) is the author/funder, who has granted medRxiv a license to display the preprint in perpetuity.

A
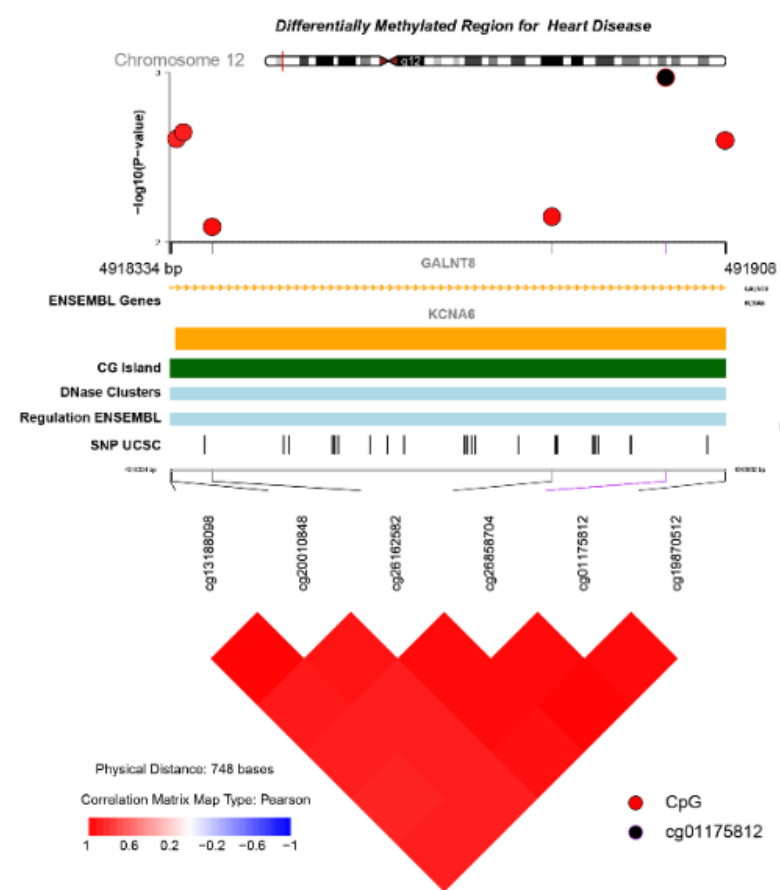

C
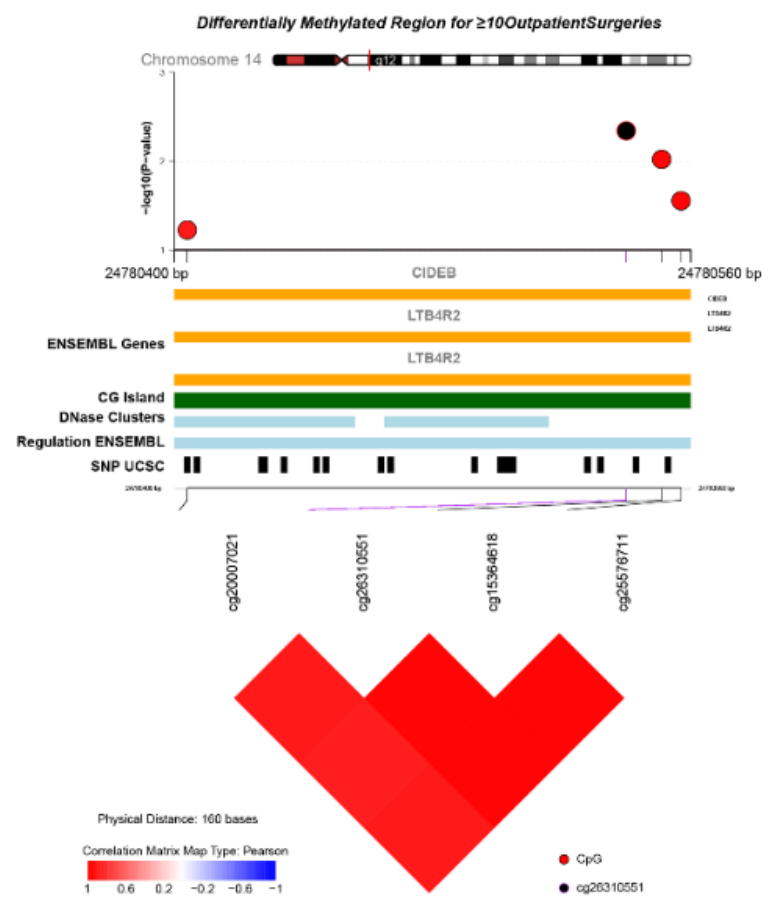

B

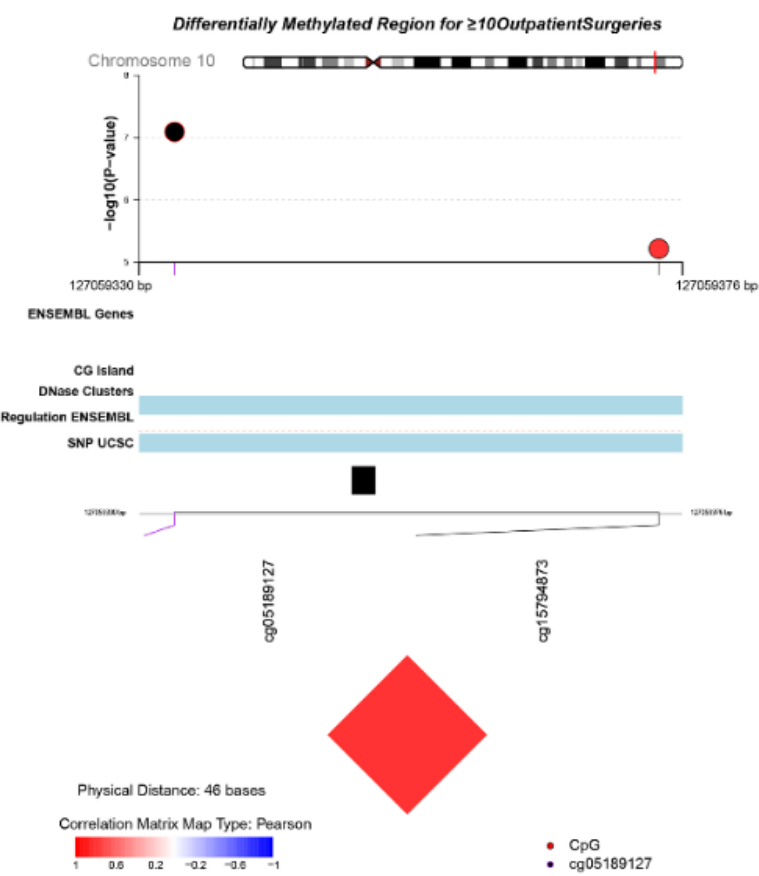

D

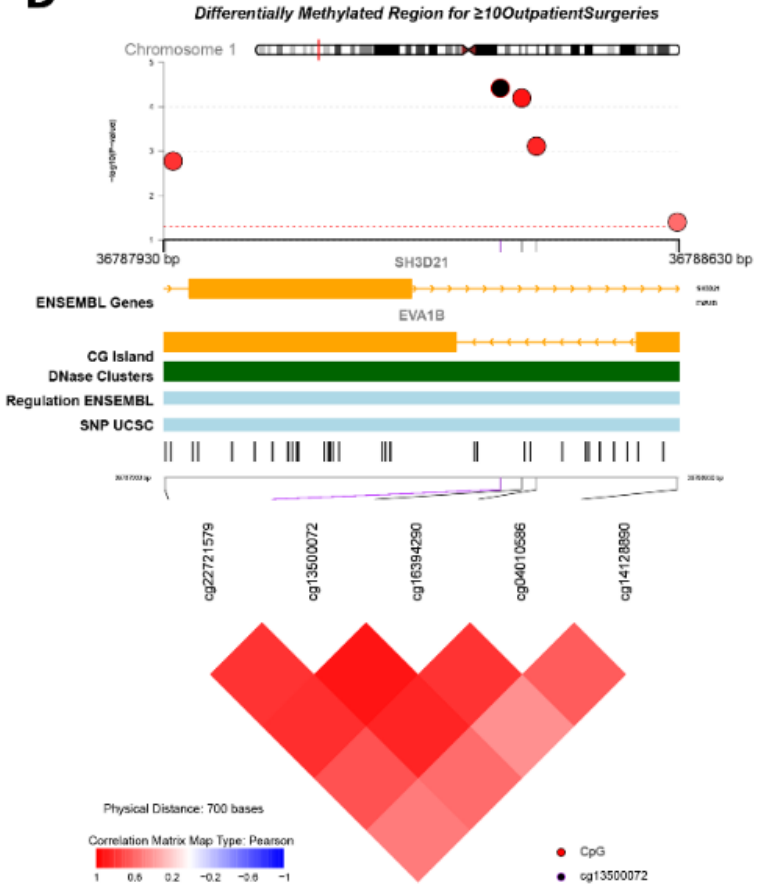

Figure 2: Differentially methylated regions in TTR-Val122Ile carriers. (A) Regional association with heart disease (B-D) Regional association with 10 or more outpatient surgeries. Each panel displays the association of sites within each region, followed by genomic location, ENSEMBL gene name, DNAse, regulation, SNP tracks (from UCSC browser) and correlation of $C p G$ sites shown as a heatmap. 
medRxiv preprint doi: https://doi.org/10.1101/2020.04.15.20066621; this version posted April 18, 2020. The copyright holder for this preprint

(which was not certified by peer review) is the author/funder, who has granted medRxiv a license to display the preprint in perpetuity.

It is made available under a CC-BY-ND 4.0 International license .

Pathak et al

\subsection{Overrepresented gene ontology and PPI networks}

Differentially methylated sites and regions were annotated to their respective genes using UCSC RefGene: hg19 genome build. The gene ontology (GO) analysis identified 15 significantly enriched pathways in GO's biological process. GLS, SKI, GALNT8, and KCNA6 are involved in protein oligomerization $\left(F_{\mathrm{pD} \text {-value }}=4.8 \mathrm{e}-03\right)$ and $K C N A 6$ and $G A L N T 8$, which are located near one another, are involved in potassium ion transport $\left(F R_{p-v a l u e}=4.9 \mathrm{e}-02\right) . F A M 12 B$ and $S K I\left(F D R_{p}\right.$ value $=4.8 \mathrm{e}-03$ to $3.2 \mathrm{e}-02$ ) participate in the development of various tissue types - myotubules, and skeletal and striated muscles (Figure 3).

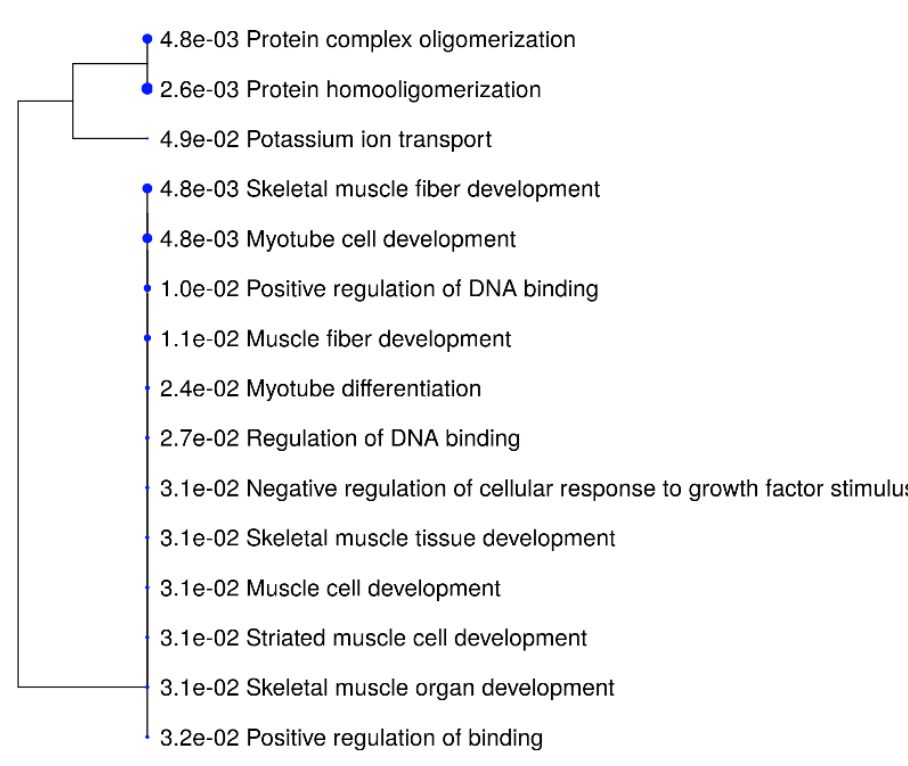

GLS SKI GALNT8 KCNA6
GLS SKI GALNT8 KCNA6
KCNA6 GALNT8
FAM129B SKI
FAM129B SKI
FAM129B SKI
FAM129B SKI
FAM129B SKI
FAM129B SKI
FAM129B SKI
FAM129B SKI
FAM129B SKI
FAM129B SKI
FAM129B SKI
FAM129B SKI

Figure 3: Enriched gene ontology (GO) biological processes. The dendrogram shows the FDR pralue of the pathway associations and are grouped by similarity of function. The genes involved in each of the processes are highlighted in orange bars.

We also investigated the methylation sites for differentially methylated functional modules using the $\mathrm{R}$ package $F E M^{30}$. The $\mathrm{CPG}$ sites are weighted based on their location in the genes, which are then mapped to a protein-protein interaction (PPI) network. For each module (i.e. PPI network) identified, the seed gene is the primary gene to which other functionally related genes are connected. For heart disease, we found the $A B C A 1$ module to be significant $(\mathrm{p}=0.001)$ and target genes identified within the module were: ABCA1, SNTB2, BLOC1S2 and LIN7B $(\mathrm{p}<0.05)$. 
medRxiv preprint doi: https://doi.org/10.1101/2020.04.15.20066621; this version posted April 18, 2020. The copyright holder for this preprint (which was not certified by peer review) is the author/funder, who has granted medRxiv a license to display the preprint in perpetuity.

The EXOSC4 gene module was associated with the phenotype of 10 or more outpatient surgeries, and it was the only gene that was a target (Figure 4; Supplementary file1; Table S4).

A
${ }^{2}$
-1.5
1
0.5
0
0.5
-1
-1.5
-2
t(DNAm)

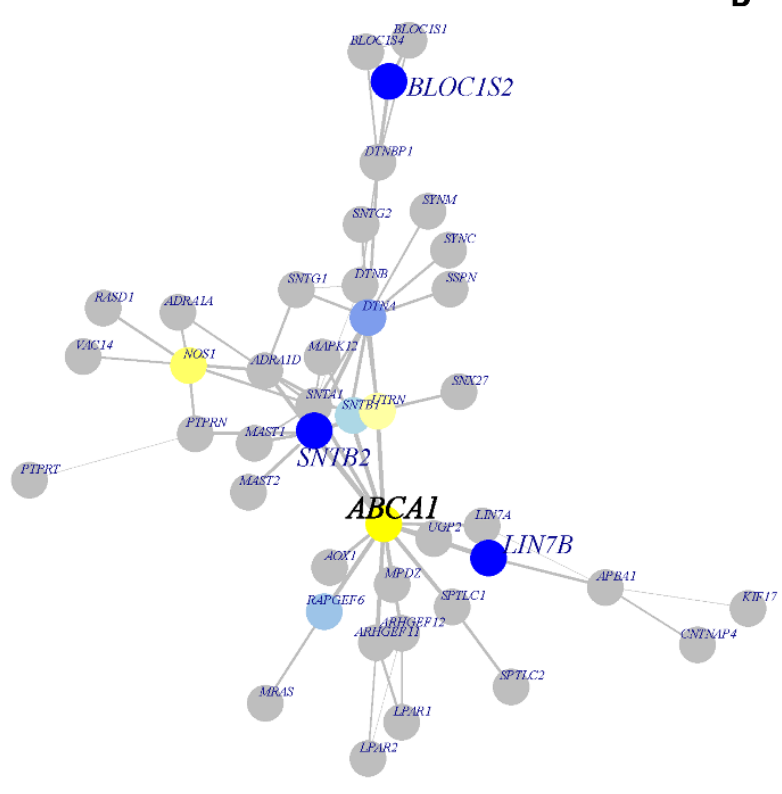

Figure 4: Functional Protein-Protein Interaction (PPI) Networks. The differentially methylated modules consist of a network of genes based on their functional connectivity using protein-protein interaction. Each module has primary gene which is connected to other target genes in the network. Each module was significant $p<0.05$ using the FEM method (see methods). The genes in blue show hypermethylation and yellow represents hypomethylation. A) $A B C A 1$ module was associated with heart disease and the significant target genes in addition to ABCA1 were SNTB2, BLOC1S2 and LINTB. B) EXOSC4 module was associated with outpatient surgeries and also was the only significant gene in the network.

\subsection{Local quantitative trait loci for methylated sites (mQTL)}

We tested SNP associations with nine methylation sites that were epigenome-wide significant with the two phenotypes investigated. The cis-mQTL loci were defined as SNPs within $\pm 1 \mathrm{Mb}$ of the significant $C p G$ site. The sites were considered significant based on an FDRp-value $<0.05$ and genomic corrected $p$-value $\left(p_{g c}<0.05\right)$. We found six SNPs, rs192528579, rs182192023, rs114553373, rs187644239, rs114896522, and rs139996037 significantly associated ( $p=4.1 e-24)$ with site cg06641417. The SNPs are in high linkage disequilibrium (LD>0.8), rs192528579 is in the intronic region of neighboring gene -- GARNL3; rs182192023, rs114553373, rs187644239 
medRxiv preprint doi: https://doi.org/10.1101/2020.04.15.20066621; this version posted April 18, 2020. The copyright holder for this preprint

(which was not certified by peer review) is the author/funder, who has granted medRxiv a license to display the preprint in perpetuity.

and rs114896522 map to LRSAM1. Rs139996037 is a non-coding transcript variant of the FAM129B.

CpG site $\operatorname{cg} 06641417$
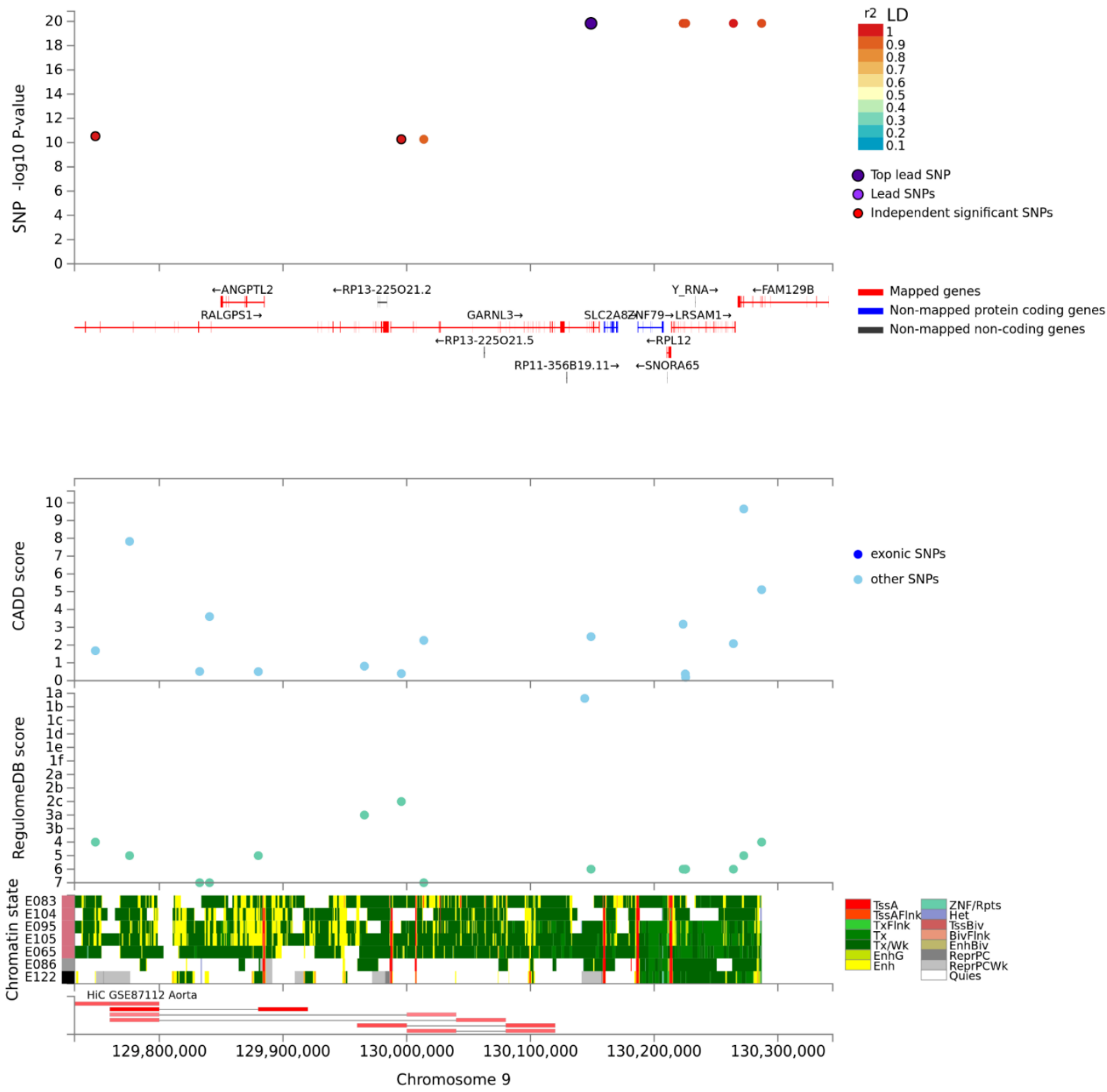

Figure 5: Local-mQTL associated with site - cg06641417 mapped to the FAM129B gene. The top panel displays single nucleotide polymorphisms (SNPs) associated with CpG site - cg06641417 as a data point and color coded based on linkage disequilibrium with the top lead SNP in purple. The $x$-axis shows gene annotation (hg19) of the region and the $y$-axis displays the -log 10 of $p$-value. The following panels present various annotations of the reported SNPS i.e. CADD - Combined Annotation Dependent Depletion, and RegulomeDB - score to identify 
medRxiv preprint doi: https://doi.org/10.1101/2020.04.15.20066621; this version posted April 18, 2020. The copyright holder for this preprint (which was not certified by peer review) is the author/funder, who has granted medRxiv a license to display the preprint in perpetuity.

regulatory variants. The bottom panel highlights the chromatin states of various regulatory features being putatively affected from chromatin markers observed in aorta tissue cell line. Visualization made in FUMA.

\subsection{Epigenetic age}

The epigenetic age (DNAm) was measured using the biological clock developed by Horvath and colleagues, which uses $353 \mathrm{CpG}$ sites $^{38}$ and also with a second clock based on $71 \mathrm{CpG}$ sites from Hannum and colleagues ${ }^{39}$. The 'Horvath' clock is considered to be a pan-tissue epigenetic clock, while the 'Hannum' clock is considered to be accurate for whole-blood tissue ${ }^{40}$. Both clocks estimated that carriers with heart disease are of older epigenetic age than carriers without heart 9 disease $\left(p_{\text {Horvath }}=0.007\right.$ and $\left.\mathrm{p}_{\text {Hannum }}=0.0009\right)($ Supplementary file 1 ; Table S6).

\subsection{Replication of methylation sites in the Italian cohort}

We tested the nine CpG sites identified in Val122Ile carriers in an independent cohort of biopsy-confirmed TTR amyloidosis cases and healthy controls. We replicated cg18546846 (intergenic; near to RP11-550A5.2; $\mathrm{p}=0.021)$ and cg06641417 (FAM129B; $\mathrm{p}=0.016)$ at nominal significance $(p<0.05)$.

\section{Discussion}

The clinical consequences of the TTR Val122Ile mutation remain underappreciated and the syndrome that accompanies this risk mutation, under-diagnosed. Individuals exhibiting early TTR-amyloidosis symptoms are more likely to be diagnosed with another condition prior to receiving the diagnosis of $T T R$-amyloidosis ${ }^{41}$. There is nonetheless a greater burden over time towards developing ventricular hypertrophy, reduced left ventricular ejection fraction, and atrial dilation, at a later age ${ }^{3,5}$. We previously showed that African-American carriers of the Val122Ile mutation had a higher prevalence of heart disease and having multiple outpatient surgeries than individuals without the mutation ${ }^{11}$. In the present study, we identified methylation changes associated with these same phenotypes in Val122Ile carriers. We also replicated two of our CpG sites near RP11-550A5.2 and in FAM129B at nominal significance in a cohort that included confirmed cases of TTR amyloidosis. Thus, we hypothesize that the epigenetic changes associated with the pathogenesis heart disease differs from the methylation profile of carriers who are not affected by the disease. Lastly, we used GeneMANIA ${ }^{34}$ to interpret the interaction 
medRxiv preprint doi: https://doi.org/10.1101/2020.04.15.20066621; this version posted April 18, 2020. The copyright holder for this preprint (which was not certified by peer review) is the author/funder, who has granted medRxiv a license to display the preprint in perpetuity.

among the significant genes (Supplementary file2). We observed that major genes identified in the present study physically interact and share pathways with TTR.

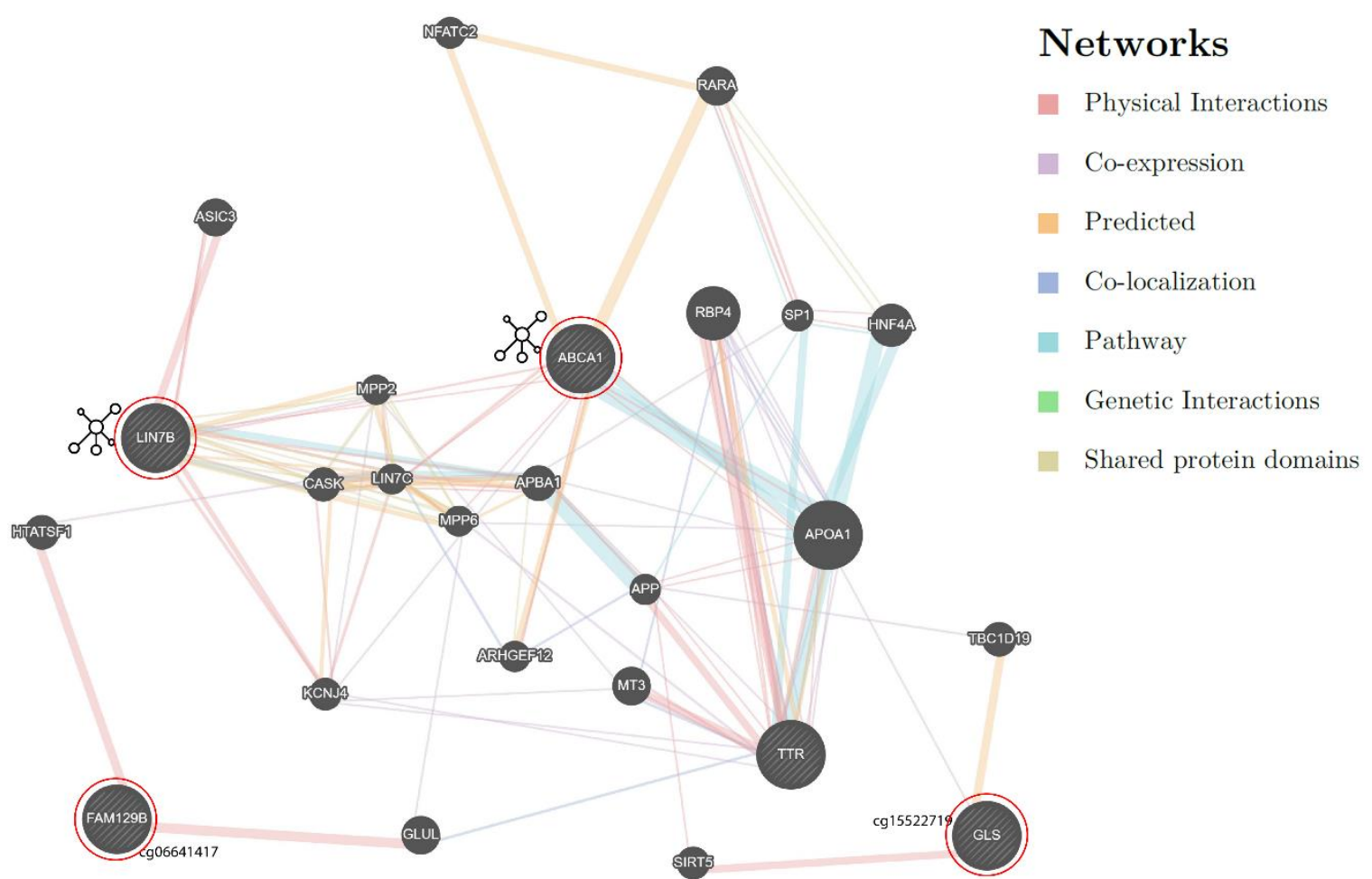

$6 \quad$ Figure 6: Network of genes for significant genic hits and their relationship with TTR. The genes (query genes) circled in red were identified from our analysis. The network shows intermediate genes that connect our query genes. Detailed information on the is provided in Supplementary file2

$A B C A 1$ (ATP binding cassette transporter A1) identified via the functional network analysis encodes a transporter of cholesterol from apolipoproteins ${ }^{42}$. $A B C A 1$ regulates Apolipoprotein $\mathrm{E}$ (ApoE) levels, with lower expression of $A B C A 1$ reducing ApoE levels. However, ApoE with ApoA1 (Apolipoprotein A) reduces amyloid deposition twice as fast as inhibition of the expression of $A p o E$. Additionally, amyloid-beta levels were the lowest for the dual-knockout of $A P P$ (which encodes amyloid precursor protein) and $A B C A 1^{43}$.

GLS (glutaminase) is a key contributor to the metabolizing of glutamine to glutamate ${ }^{44}$. Amyloid-beta-treated neurons show elevated glutaminase expression, which increases glutamate levels and disrupts calcium neural regulation ${ }^{45}$. Additionally, neurofibrillary tangles 
medRxiv preprint doi: https://doi.org/10.1101/2020.04.15.20066621; this version posted April 18, 2020. The copyright holder for this preprint

(which was not certified by peer review) is the author/funder, who has granted medRxiv a license to display the preprint in perpetuity.

have been shown to coexist with higher glutaminase activity ${ }^{46}$. The hypomethylated site in the transcription start site of the GLS gene may indicate its potential involvement in the central nervous system, which supports the recent finding of cerebral amyloid angiopathy in individuals with mutated TTR cardiac amyloidosis ${ }^{47}$. FAM129B (aliases; MEG-3 and NIBAN2) is downregulated in tissues with amyloid deposition and animal studies have shown that enhancing the expression of $F A M 129 B$ reduces oxidative damage by reducing amyloid-beta production via PI3K/Akt signaling ${ }^{48}$. Cardiac hypertrophy increases the risk of heart failure. $F A M 129 B$ is overexpressed in heart failure samples, and rodent experiments indicate a potential role of the gene in the apoptosis of cardiac myocytes after myocardial infarction ${ }^{49}$. Rescuing the expression levels of $F A M 129 B$ reverses hypertrophic responses, thus the hypomethylation of the CpG site in FAM129B observed in our finding supports the overexpression of the gene in heart failure ${ }^{50}$. The African-American population has a high prevalence of diabetes ${ }^{51}$. FAM129B is also overexpressed in cardiomyocytes under high glucose concentration reflecting its role in diabetic cardiomyopathy $^{52}$. Although $S K I$ is an inhibitor of TGF-beta-induced fibrosis and is under expressed in cardiac fibrosis, other epigenetic modulators such as miRNAs-34a and 93-c affect both SKI and TGF-beta, targeting the inhibitory factors of SKI, which could rescue cardiac fibrosis $^{53}$. The gene enrichment analysis identified a role for $F A M 129 B$ and $S K I$ in the development of myotube cells and skeletal muscle fiber and organ, and striated muscle cell development.

One of the clinical findings associated with cardiac amyloidosis is increased left ventricular wall thickness, which can lead to heart failure ${ }^{54}$. Electrical perturbations resulting from lower potassium repolarizing current leads to a prolonged action potential in heart failure ${ }^{55}$. The role of KCNA6 and GALNT8 is associated with potassium ion transport and the transmembrane transport complexes. One of the cardiovascular symptoms of the TTR amyloidosis is pronounced diastolic hypertension ${ }^{6}$, and diastolic dysfunction is one of the symptoms associated with transthyretin amyloidosis ${ }^{56}$. WDR27 was reported to be differentially methylated in individuals with significant differences in diastolic blood pressure ${ }^{26}$. 
medRxiv preprint doi: https://doi.org/10.1101/2020.04.15.20066621; this version posted April 18, 2020. The copyright holder for this preprint

(which was not certified by peer review) is the author/funder, who has granted medRxiv a license to display the preprint in perpetuity.

Aging is a common denominator to the symptomology of Val122Ile and DNA methylation ${ }^{57}$. Age-related methylation changes measured via "epigenetic clocks" help to identify molecular aging and its disconnect with chronological age. The Horvath clock based on 353 CpG sites and the Hannum clock based on $71 \mathrm{CpG}$ sites have been extensively replicated in various tissues ${ }^{58}$. While these clocks were developed using blood tissues ${ }^{38,39}$, Horvath's clock is validated across multiple tissues, while Hannum's clock is more consistent in samples originating from blood tissues. Higher epigenetically derived age has been associated with several cardiovascular disease traits. Hypermethylation of genes that are protective against heart disease, lead to cardiovascular aging and increased risk for coronary disease ${ }^{59}$. The dysregulation of the $A B C A 1$ gene, the product of which is involved in the transport of cholesterol from the periphery to liver tissue $^{60}$ has been associated with different cardiovascular pathologies. The hypermethylation of the $A B C A 1$ promoter region silences its expression and is associated with coronary artery disease ${ }^{61}$. In contrast, the increased expression of $A B C A 1$ regulated by $A p o A 1$ leads to reverse cholesterol efflux in hepatic tissue ${ }^{62}$. Elevated high density lipoprotein (HDL) in the liver is a target site for serum amyloid $A$, an acute phase response protein that is expressed during amyloidosis $^{63}$. The observed hypomethylation of $A B C A 1$ and putative increase in gene expression underscores its likely involvement in shifting the methylation milieu and could perhaps explain the cardiac symptomology in a comparatively younger group of Val122Ile carriers.

These findings provide unique insights into epigenomic contrasts related to symptomology in Val122Ile carriers. However, our study has limitations. First, we investigated the Val122Ile polymorphism only for heart disease, though it is possible that we could identify additional differences with individuals who are non-Val122Ile carriers or who present with wild-type transthyretin amyloidosis. Additionally, due to the low frequency of the disease-causing mutation investigated, our study suffers from an imbalance in the ratio of cases to controls. Although the permutation analysis accounting for this imbalance confirmed our results and we replicated two associations in an independent cohort (with mostly different risk variants), our findings would benefit from replication in a larger, more balanced study. 
medRxiv preprint doi: https://doi.org/10.1101/2020.04.15.20066621; this version posted April 18, 2020. The copyright holder for this preprint

\section{Conclusion}

Our study is the first to explore the epigenetic changes in TTR Val122Ile carriers. Certain Val122Ile carriers in our study presented with heart disease earlier than usually reported by individuals affected by cardiac amyloidosis. This could be due to modifier effects accelerating the pathogenicity of Val122Ile mutation. Due to the underestimated clinical penetrance of the mutation in the African American population, we leveraged an external secondary dataset with confirmed clinical phenotype as a random population sample. The purpose of this study was to understand possible non-coding mechanisms that may explain the heterogeneous phenotypes observed in Val122Ile carriers with history of heart disease. The epigenetic changes identified affect the regulation of genes involved in the transport of amyloid and regulating striated and smooth muscle, which form key components of amyloidosis and cardiac tissue susceptibility. These findings provide higher resolution on mechanisms underlying the TTR-Val122Ile mutation.

\section{Acknowledgments}

The study was supported by 'Global ASPIRE TTR Amyloidosis Competitive Grant' from Pfizer

Inc. We are grateful to the participants of the Yale-Penn cohort, which was funded under grants RC2 DA028909, R01 DA12690, R01 DA12849, R01 DA18432, R01AA11330, and R01 AA017535. The investigation conducted in the Italian cohort was supported by an Investigator-Initiated Research from Pfizer Inc. to the University of Rome "Tor Vergata". The content reported in the manuscript is solely the responsibility of the authors and does not represent the official views of the NIH or Pfizer. The funding agencies had no role in the study design, data analysis, and results interpretation of the present study.

Full summary statistics of the epigenome-wide analysis will be made available post-publication by contacting the corresponding author - R.P. listed on the manuscript.

\section{Author contributions}

R.P. and G.A.P. conceptualized the research design and R.P. received funding for the study. J.G. and H. K designed the Yale-Penn study, and H.K. and J.G. oversaw the recruitment and assessment of the Yale-Penn sample. The analysis was performed by G.A.P. All authors were 
medRxiv preprint doi: https://doi.org/10.1101/2020.04.15.20066621; this version posted April 18, 2020. The copyright holder for this preprint (which was not certified by peer review) is the author/funder, who has granted medRxiv a license to display the preprint in perpetuity.

involved in data interpretation, manuscript preparation, review, and critical feedback. The funding for Yale-Penn was obtained by J.G and H.K.

\section{Conflicts of Interest}

H.R.K. is a member of the American Society of Clinical Psychopharmacology's Alcohol Clinical Trials Initiative, which over the last three years was sponsored by Alkermes, Ethypharm, Indivior, Lilly, Lundbeck, Otsuka, Pfizer, Arbor Pharmaceuticals, and Amygdala Neurosciences, Inc. H.R.K. and J.G. are named as inventors on PCT patent application \#15/878,640 entitled: "Genotypeguided dosing of opioid agonists," filed on 24 January 2018. The other authors report no conflict of interest.

\section{References}

1. Kristen AV, Maurer MS, Rapezzi C, Mundayat R, Suhr OB, Damy T, THAOS investigators. Impact of genotype and phenotype on cardiac biomarkers in patients with transthyretin amyloidosis - Report from the Transthyretin Amyloidosis Outcome Survey (THAOS). PLoS One. 2017;12:e0173086.

2. Jacobson DR, Alexander AA, Tagoe C, Garvey WT, Williams SM, Tishkoff S, Modiano D, Sirima SB, Kalidi I, Toure A, Buxbaum JN. The prevalence and distribution of the amyloidogenic transthyretin (TTR) V122I allele in Africa. Mol Genet Genomic Med. 2016;4:548-556.

3. Buxbaum JN, Ruberg FL. Transthyretin V122I (pV142I)* cardiac amyloidosis: an agedependent autosomal dominant cardiomyopathy too common to be overlooked as a cause of significant heart disease in elderly African Americans. Genet Med. 2017;19:733-742.

4. Maurer MS, Hanna M, Grogan M, Dispenzieri A, Witteles R, Drachman B, Judge DP, Lenihan DJ, Gottlieb SS, Shah SJ, Steidley DE, Ventura H, Murali S, Silver MA, Jacoby D, Fedson S, Hummel SL, Kristen AV, Damy T, Planté-Bordeneuve V, Coelho T, Mundayat R, Suhr OB, Waddington Cruz M, Rapezzi C, THAOS Investigators. Genotype and phenotype of 
medRxiv preprint doi: https://doi.org/10.1101/2020.04.15.20066621; this version posted April 18, 2020. The copyright holder for this preprint

transthyretin cardiac amyloidosis: THAOS (transthyretin amyloid outcome survey). J Am Coll Cardiol. 2016;68:161-172.

5. Mankad AK, Shah KB. Transthyretin Cardiac Amyloidosis. Curr Cardiol Rep. 2017;19:97.

6. Shah KB, Mankad AK, Castano A, Akinboboye OO, Duncan PB, Fergus IV, Maurer MS. Transthyretin cardiac amyloidosis in black americans. Circ Heart Fail. 2016;9:e002558.

7. Jercan A, Ene A, Jurcut R, Draghici M, Badelita S, Dragomir M, Dobrea C, Popescu M, Jardan D, Stoica E, Iacob S, Codita I, Stan C, Coriu D. Clinical characteristics in patients with hereditary amyloidosis with Glu54GIn transthyretin identified in the Romanian population. Orphanet J Rare Dis. 2020;15:34.

8. Karam C, Dimitrova D, Christ M, Heitner SB. Carpal tunnel syndrome and associated symptoms as first manifestation of hATTR amyloidosis. Neurol Clin Pract. 2019;9:309-313.

9. Milandri A, Farioli A, Gagliardi C, Longhi S, Salvi F, Curti S, Foffi S, Caponetti AG, Lorenzini M, Ferlini A, Rimessi P, Mattioli S, Violante FS, Rapezzi C. Carpal tunnel syndrome in cardiac amyloidosis: implications for early diagnosis and prognostic role across the spectrum of aetiologies. Eur J Heart Fail. 2020;

10. De Lillo A, De Angelis F, Di Girolamo M, Luigetti M, Frusconi S, Manfellotto D, Fuciarelli M, Polimanti R. Phenome-wide association study of TTR and RBP4 genes in 361,194 individuals reveals novel insights in the genetics of hereditary and wildtype transthyretin amyloidoses. Hum Genet. 2019;138:1331-1340.

11. Polimanti R, Nuñez $Y Z$, Gelernter J. Increased Risk of Multiple Outpatient Surgeries in African-American Carriers of Transthyretin Val122Ile Mutation Is Modulated by Non-Coding Variants. J Clin Med. 2019;8.

12. Steiner CA, Karaca Z, Moore BJ. Surgeries in hospital-based ambulatory surgery and hospital inpatient settings, 2014: statistical brief\# 223. ... -Ambulatory-Inpatient .... 2017;

13. Rubin J, Alvarez J, Teruya S, Castano A, Lehman RA, Weidenbaum M, Geller JA, Helmke S, Maurer MS. Hip and knee arthroplasty are common among patients with transthyretin cardiac amyloidosis, occurring years before cardiac amyloid diagnosis: can we identify affected patients earlier? Amyloid. 2017;24:226-230. 
medRxiv preprint doi: https://doi.org/10.1101/2020.04.15.20066621; this version posted April 18, 2020. The copyright holder for this preprint (which was not certified by peer review) is the author/funder, who has granted medRxiv a license to display the preprint in perpetuity.

14. Iorio A, De Lillo A, De Angelis F, Di Girolamo M, Luigetti M, Sabatelli M, Pradotto L, Mauro A, Mazzeo A, Stancanelli C, Perfetto F, Frusconi S, My F, Manfellotto D, Fuciarelli M, Polimanti R. Non-coding variants contribute to the clinical heterogeneity of TTR amyloidosis. Eur J Hum Genet. 2017;25:1055-1060.

15. Iorio A, De Angelis F, Di Girolamo M, Luigetti M, Pradotto LG, Mazzeo A, Frusconi S, My F, Manfellotto D, Fuciarelli M, Polimanti R. Population diversity of the genetically determined TTR expression in human tissues and its implications in TTR amyloidosis. BMC Genomics. 2017; 18:254.

16. Polimanti R, Di Girolamo M, Manfellotto D, Fuciarelli M. In silico analysis of TTR gene (coding and non-coding regions, and interactive network) and its implications in transthyretinrelated amyloidosis. Amyloid. 2014;21:154-162.

17. Polimanti R, Di Girolamo M, Manfellotto D, Fuciarelli M. Functional variation of the transthyretin gene among human populations and its correlation with amyloidosis phenotypes. Amyloid. 2013;20:256-262.

18. Pathak GA, Silzer TK, Sun J, Zhou Z, Daniel AA, Johnson L, O'Bryant S, Phillips NR, Barber RC. Genome-Wide Methylation of Mild Cognitive Impairment in Mexican Americans Highlights Genes Involved in Synaptic Transport, Alzheimer's Disease-Precursor Phenotypes, and Metabolic Morbidities. J Alzheimers Dis. 2019;72:733-749.

19. Zoghbi HY, Beaudet AL. Epigenetics and human disease. Cold Spring Harb Perspect Biol. 2016;8:a019497.

20. Planté-Bordeneuve V, Said G. Familial amyloid polyneuropathy. Lancet Neurol. 2011;10:1086-1097.

21. Hachiya T, Furukawa R, Shiwa Y, Ohmomo H, Ono K, Katsuoka F, Nagasaki M, Yasuda J, Fuse N, Kinoshita K, Yamamoto M, Tanno K, Satoh M, Endo R, Sasaki M, Sakata K, Kobayashi S, Ogasawara K, Hitomi J, Sobue K, Shimizu A. Genome-wide identification of inter-individually variable DNA methylation sites improves the efficacy of epigenetic association studies. NPJ Genom Med. 2017;2:11. 
medRxiv preprint doi: https://doi.org/10.1101/2020.04.15.20066621; this version posted April 18, 2020. The copyright holder for this preprint (which was not certified by peer review) is the author/funder, who has granted medRxiv a license to display the preprint in perpetuity.

22. Polimanti R, Meda SA, Pearlson GD, Zhao H, Sherva R, Farrer LA, Kranzler HR, Gelernter J. S100A10 identified in a genome-wide gene $\times$ cannabis dependence interaction analysis of risky sexual behaviours. J Psychiatry Neurosci. 2017;42:252-261.

23. Polimanti R, Kaufman J, Zhao H, Kranzler HR, Ursano RJ, Kessler RC, Gelernter J, Stein MB. A genome-wide gene-by-trauma interaction study of alcohol misuse in two independent cohorts identifies PRKG1 as a risk locus. Mol Psychiatry. 2018;23:154-160.

24. Polimanti R, Wang Q, Meda SA, Patel KT, Pearlson GD, Zhao H, Farrer LA, Kranzler HR, Gelernter J. The Interplay Between Risky Sexual Behaviors and Alcohol Dependence: Genome-Wide Association and Neuroimaging Support for LHPP as a Risk Gene. Neuropsychopharmacology. 2017;42:598-605.

25. Polimanti $R$, Zhang $H$, Smith AH, Zhao H, Farrer LA, Kranzler HR, Gelernter J. Genome-wide association study of body mass index in subjects with alcohol dependence. Addict Biol. 2017;22:535-549.

26. Iorio A, De Angelis F, Di Girolamo M, Luigetti M, Pradotto L, Mauro A, Manfellotto D, Fuciarelli M, Polimanti R. Most recent common ancestor of TTR Val30Met mutation in Italian population and its potential role in genotype-phenotype correlation. Amyloid. 2015;22:7378.

27. Tian Y, Morris TJ, Webster AP, Yang Z, Beck S, Feber A, Teschendorff AE. ChAMP: updated methylation analysis pipeline for Illumina BeadChips. Bioinformatics. 2017;33:3982-3984.

28. McCartney DL, Stevenson AJ, Hillary RF, Walker RM, Bermingham ML, Morris SW, Clarke TK, Campbell A, Murray AD, Whalley HC, Porteous DJ, Visscher PM, McIntosh AM, Evans KL, Deary IJ, Marioni RE. Epigenetic signatures of starting and stopping smoking. EBioMedicine. 2018;37:214-220.

29. Barfield RT, Kilaru V, Smith AK, Conneely KN. CpGassoc: an R function for analysis of DNA methylation microarray data. Bioinformatics. 2012;28:1280-1281.

30. Jiao $Y$, Widschwendter $M$, Teschendorff AE. A systems-level integrative framework for genome-wide DNA methylation and gene expression data identifies differential gene expression modules under epigenetic control. Bioinformatics. 2014;30:2360-2366. 
medRxiv preprint doi: https://doi.org/10.1101/2020.04.15.20066621; this version posted April 18, 2020. The copyright holder for this preprint (which was not certified by peer review) is the author/funder, who has granted medRxiv a license to display the preprint in perpetuity.

31. Ge SX, Jung D, Yao R. ShinyGO: a graphical enrichment tool for animals and plants. Bioinformatics. 2019;

32. Shabalin AA. Matrix eQTL: ultra fast eQTL analysis via large matrix operations. Bioinformatics. 2012;28:1353-1358.

33. Pidsley R, Y Wong CC, Volta M, Lunnon K, Mill J, Schalkwyk LC. A data-driven approach to preprocessing Illumina 450K methylation array data. BMC Genomics. 2013;14:293.

34. Montojo J, Zuberi K, Rodriguez H, Bader GD, Morris Q. GeneMANIA: Fast gene network construction and function prediction for Cytoscape. [version 1; peer review: 2 approved]. F1000Res. 2014;3:153.

35. Martin TC, Yet I, Tsai P-C, Bell JT. coMET: visualisation of regional epigenome-wide association scan results and DNA co-methylation patterns. BMC Bioinformatics. 2015;16:131.

36. Watanabe K, Taskesen E, van Bochoven A, Posthuma D. Functional mapping and annotation of genetic associations with FUMA. Nat Commun. 2017;8:1826.

37. Bibikova M, Barnes B, Tsan C, Ho V, Klotzle B, Le JM, Delano D, Zhang L, Schroth GP, Gunderson KL, Fan J-B, Shen R. High density DNA methylation array with single CpG site resolution. Genomics. 2011;98:288-295.

38. Horvath S. DNA methylation age of human tissues and cell types. Genome Biol. 2013;14:R115.

39. Hannum G, Guinney J, Zhao L, Zhang L, Hughes G, Sadda S, Klotzle B, Bibikova M, Fan J-B, Gao Y, Deconde R, Chen M, Rajapakse I, Friend S, Ideker T, Zhang K. Genome-wide methylation profiles reveal quantitative views of human aging rates. Mo/ Cell. 2013;49:359367.

40. Zhang Q, Vallerga CL, Walker RM, Lin T, Henders AK, Montgomery GW, He J, Fan D, Fowdar J, Kennedy M, Pitcher T, Pearson J, Halliday G, Kwok JB, Hickie I, Lewis S, Anderson T, Silburn PA, Mellick GD, Harris SE, Redmond P, Murray AD, Porteous DJ, Haley CS, Evans KL, McIntosh AM, Yang J, Gratten J, Marioni RE, Wray NR, Deary IJ, McRae AF, Visscher PM. 
medRxiv preprint doi: https://doi.org/10.1101/2020.04.15.20066621; this version posted April 18, 2020. The copyright holder for this preprint (which was not certified by peer review) is the author/funder, who has granted medRxiv a license to display the preprint in perpetuity.

Improved precision of epigenetic clock estimates across tissues and its implication for biological ageing. Genome Med. 2019;11:54.

41. Bishop E, Brown EE, Fajardo J, Barouch LA, Judge DP, Halushka MK. Seven factors predict a delayed diagnosis of cardiac amyloidosis. Amyloid. 2018;25:174-179.

42. Sasaki M, Komatsu T, Ikewaki K. Impact of Hepatic ABCA1 (ATP-Binding Cassette Transporter A1) Deletion on Reverse Cholesterol Transport A New Clue in Solving Complex HDL (High-Density Lipoprotein) Metabolism. Arterioscler Thromb Vasc Biol. 2019;39:16991701.

43. Koldamova R, Staufenbiel M, Lefterov I. Lack of ABCA1 considerably decreases brain ApoE level and increases amyloid deposition in APP23 mice. J Biol Chem. 2005;280:43224-43235.

44. Cooper AJL, Jeitner TM. Central role of glutamate metabolism in the maintenance of nitrogen homeostasis in normal and hyperammonemic brain. Biomolecules. 2016;6.

45. Revett TJ, Baker GB, Jhamandas J, Kar S. Glutamate system, amyloid B peptides and tau protein: functional interrelationships and relevance to Alzheimer disease pathology. $J$ Psychiatry Neurosci. 2013;38:6-23.

46. Fuchsberger T, Martínez-Bellver S, Giraldo E, Teruel-Martí V, Lloret A, Viña J. A $\beta$ Induces Excitotoxicity Mediated by APC/C-Cdh1 Depletion That Can Be Prevented by Glutaminase Inhibition Promoting Neuronal Survival. Sci Rep. 2016;6:31158.

47. Schaich CL, Maurer MS, Nadkarni NK. Amyloidosis of the brain and heart: two sides of the same coin? JACC Heart Fail. 2019;7:129-131.

48. Yi J, Chen B, Yao X, Lei Y, Ou F, Huang F. Upregulation of the IncRNA MEG3 improves cognitive impairment, alleviates neuronal damage, and inhibits activation of astrocytes in hippocampus tissues in Alzheimer's disease through inactivating the PI3K/Akt signaling pathway. J Cell Biochem. 2019;120:18053-18065.

49. Wu H, Zhao Z-A, Liu J, Hao K, Yu Y, Han X, Li J, Wang Y, Lei W, Dong N, Shen Z, Hu S. Long noncoding RNA Meg3 regulates cardiomyocyte apoptosis in myocardial infarction. Gene Ther. 2018;25:511-523. 
medRxiv preprint doi: https://doi.org/10.1101/2020.04.15.20066621; this version posted April 18, 2020. The copyright holder for this preprint (which was not certified by peer review) is the author/funder, who has granted medRxiv a license to display the preprint in perpetuity.

50. Zhang J, Liang Y, Huang X, Guo X, Liu Y, Zhong J, Yuan J. STAT3-induced upregulation of IncRNA MEG3 regulates the growth of cardiac hypertrophy through miR-361-5p/HDAC9 axis. Sci Rep. 2019;9:460.

51. Chow EA, Foster H, Gonzalez V, McIver L. The disparate impact of diabetes on racial/ethnic minority populations. Clinical Diabetes. 2012;30:130-133.

52. Chen Y, Zhang Z, Zhu D, Zhao W, Li F. Long non-coding RNA MEG3 serves as a ceRNA for microRNA-145 to induce apoptosis of AC16 cardiomyocytes under high glucose condition. Biosci Rep. 2019;39.

53. Zhang $\mathrm{C}$, Zhang $\mathrm{Y}$, Zhu H, Hu J, Xie Z. MiR-34a/miR-93 target c-Ski to modulate the proliferaton of rat cardiac fibroblasts and extracellular matrix deposition in vivo and in vitro. Cell Signal. 2018;46:145-153.

54. Suresh R, Grogan M, Maleszewski JJ, Pellikka PA, Hanna M, Dispenzieri A, Pereira NL. Advanced cardiac amyloidosis associated with normal interventricular septal thickness: an uncommon presentation of infiltrative cardiomyopathy. $\mathcal{A m}$ Soc Echocardiogr. 2014;27:440-447.

55. Yang K-C, Nerbonne JM. Mechanisms contributing to myocardial potassium channel diversity, regulation and remodeling. Trends Cardiovasc Med. 2016;26:209-218.

56. González-Duarte A, Barroso F, Mundayat R, Shapiro B. Blood pressure and orthostatic hypotension as measures of autonomic dysfunction in patients from the transthyretin amyloidosis outcomes survey (THAOS). Auton Neurosci. 2019;222:102590.

57. Maurer MS, Mundayat R, Rapezzi C. Reply: Val122Ile mt-ATTR Has a Worse Survival Than wt-ATTR Cardiac Amyloidosis. J Am Coll Cardiol. 2017;69:758-759.

58. Unnikrishnan A, Freeman WM, Jackson J, Wren JD, Porter H, Richardson A. The role of DNA methylation in epigenetics of aging. Pharmacol Ther. 2019;195:172-185.

59. Zhang W, Song M, Qu J, Liu G-H. Epigenetic modifications in cardiovascular aging and diseases. Circ Res. 2018;123:773-786. 
medRxiv preprint doi: https://doi.org/10.1101/2020.04.15.20066621; this version posted April 18, 2020. The copyright holder for this preprint

(which was not certified by peer review) is the author/funder, who has granted medRxiv a license to display the preprint in perpetuity.

60. Ghaznavi H, Mahmoodi K, Soltanpour MS. A preliminary study of the association between the ABCA1 gene promoter DNA methylation and coronary artery disease risk. Mol Biol Res Commun. 2018;7:59-65.

61. Guay S-P, Légaré C, Houde A-A, Mathieu P, Bossé Y, Bouchard L. Acetylsalicylic acid, aging and coronary artery disease are associated with ABCA1 DNA methylation in men. Clin Epigenetics. 2014;6:14.

62. Vaisman BL, Lambert G, Amar M, Joyce C, Ito T, Shamburek RD, Cain WJ, Fruchart-Najib J, Neufeld ED, Remaley AT, Brewer HB, Santamarina-Fojo S. ABCA1 overexpression leads to hyperalphalipoproteinemia and increased biliary cholesterol excretion in transgenic mice. $J$ Clin Invest. 2001;108:303-309.

63. Yang M, Liu Y, Dai J, Li L, Ding X, Xu Z, Mori M, Miyahara H, Sawashita J, Higuchi K. Apolipoprotein A-II induces acute-phase response associated AA amyloidosis in mice through conformational changes of plasma lipoprotein structure. Sci Rep. 2018;8:5620. 
A $107 \quad \triangle$ Hypermethylation

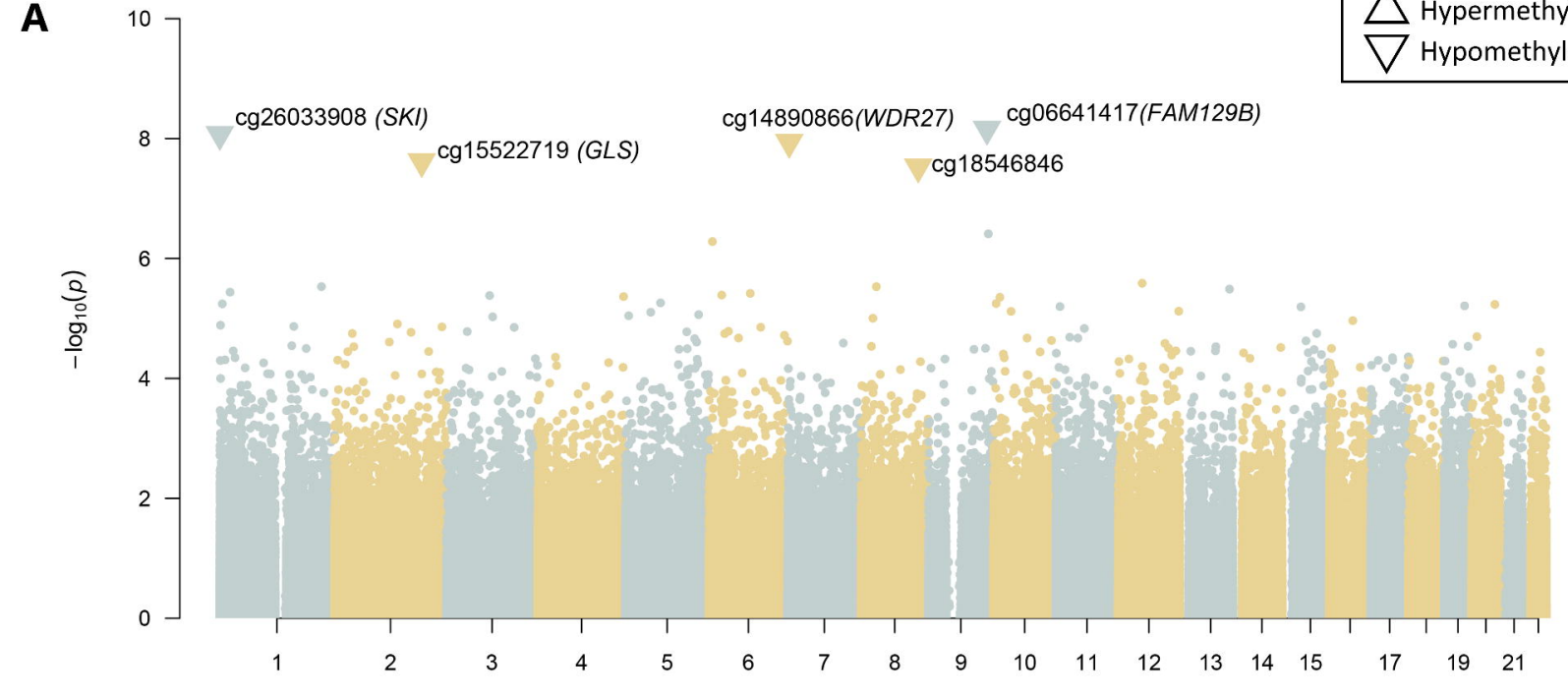

B

Chromosome

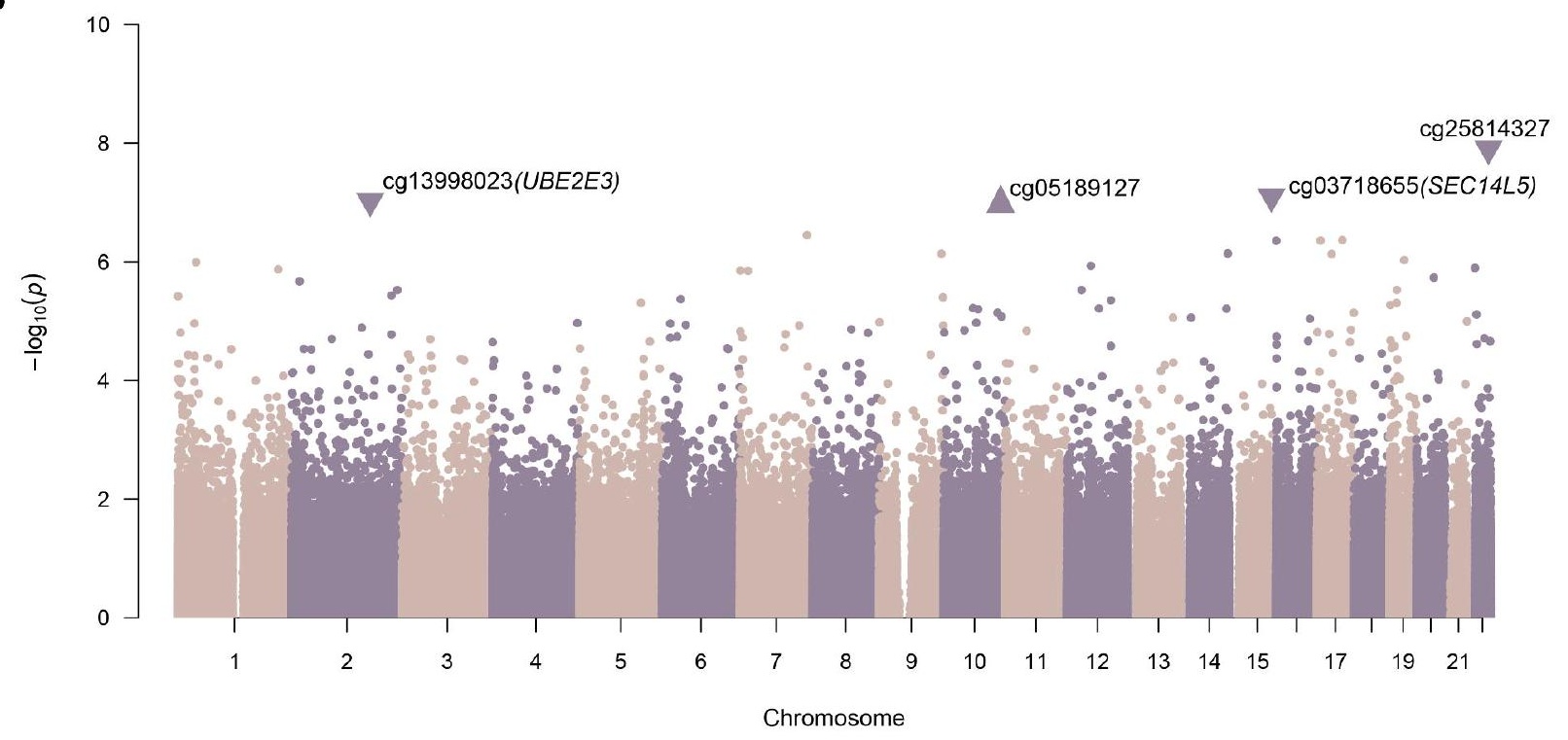




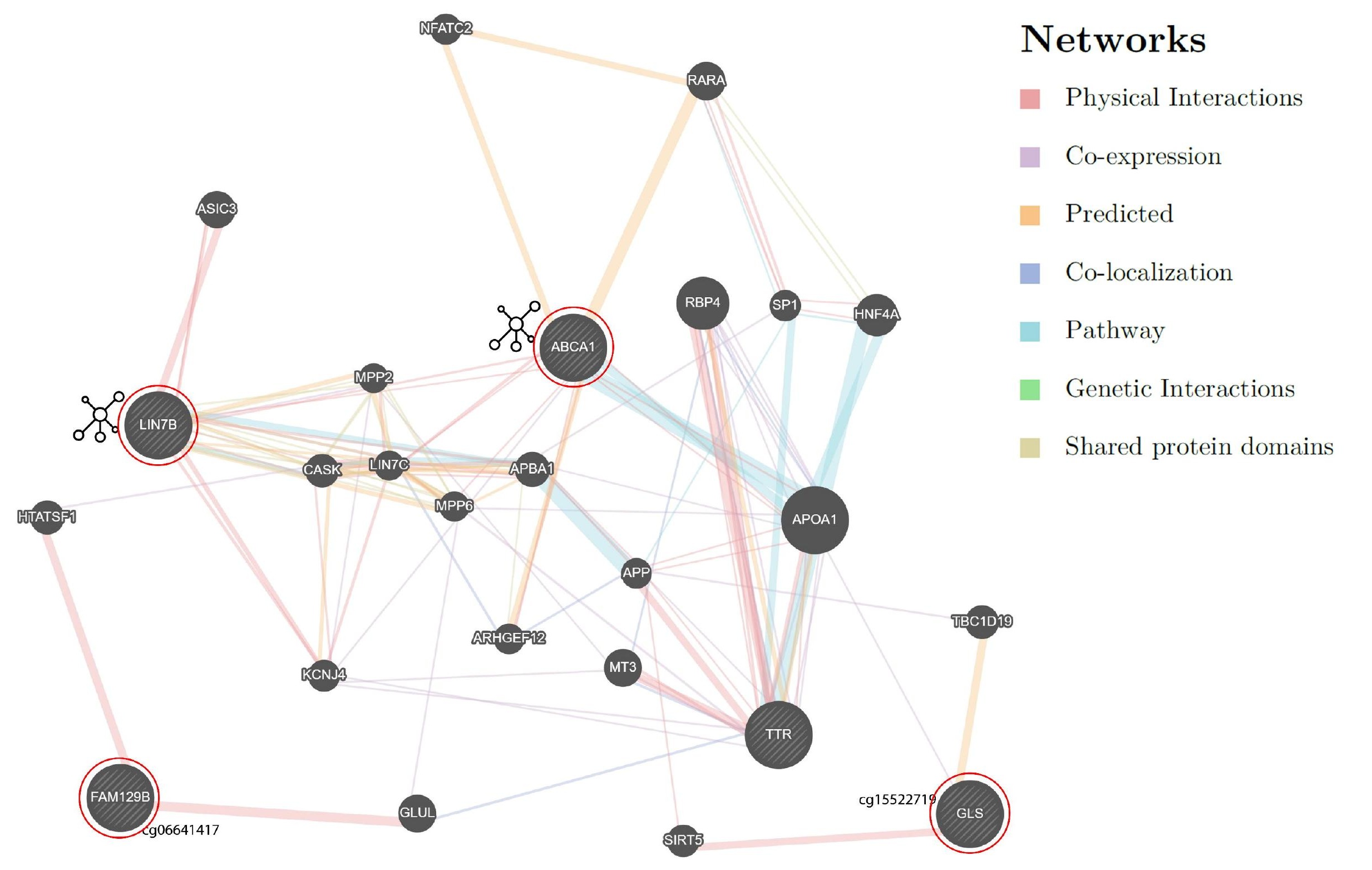

